\title{
Curriculum Models and Identity: Three Stories of Early Childhood Teachers
}

\author{
Marta Cabral \\ Universidade de Lisboa, Instituto de Educação \\ Teachers College, Columbia University
}

\begin{abstract}
Questions of professional identity are discussed in this paper, based on a master's thesis defended at Universidade de Lisboa. The role of curriculum models in the construction of three early childhood teachers' professional identities is briefly examined and discussed. As each teacher works with a different curriculum, their ideas on the importance of "belonging" to a certain pedagogical model are presented and considered.

The literature review is based on issues of professional identity, specifically in early childhood teaching and education; on the historical origin, characterization and definition of curriculum models; and on the two studied curriculum models: Waldorf Pedagogy and MEM - Modelo Movimento Escola Moderna ("New School Movement").

Using qualitative methodologies and framed within the assumptions of interpretative investigation, symbolic interactionism and ethnography, field investigation was conducted with three teachers in three different early childhood settings, each working with different models: Waldorf Pedagogy, Movimento Escola Moderna, and a third teacher who did not adopt any particular model in her practice.
\end{abstract}

\section{Introduction}

This research aims to understand to what extent working within the frame of a curriculum model influences the professional identity of early childhood teachers. It develops in a multiple-case study, regarding each specific set of data in the individual dimension of the case it belongs to, but also relating it to the other individual cases. In the framework of qualitative research, this study presents the main characteristics that, according to Bogdan and Biklen [1], define this kind of research: the researcher is the main investigative tool; the study has a descriptive nature; the focus is on the research process; data is analyzed inductively; and chief importance is given to the informants, their thoughts and their representations on the subject.

The participants in this study, three early childhood teachers teaching in private schools with a strong tradition of working within a defined curriculum or philosophy, were selected according to four different criteria: 1) having made an informed professional choice to work within the specific pedagogical model they do; 2) exhibiting a personal connection to the chosen model and a personal investment in their teaching; 3) having a solid teaching practice within the model for at least five years, having reached their "teaching maturity" [2]; 4) showing a willingness to participate in the study. Data collection took place in three schools, and consisted of semi-directive interviews with both the 
teachers and the school directors, observations of the teachers in their classroom practices, field-notes, and analysis of schools' documentation. Data was analyzed and triangulated through content analysis of interviews, classroom materials, written documentation and observations.

\section{Questions of professional identity}

Questions of identity have a place in any given profession, and in a field as vast as education take many forms and meanings. In addressing teachers' professional identities, three different and co-existent aspects need to be considered, representing three co-dependent realms within the notion of identity [3]: personal identity, which grounds individuals in their communities [4]; professional identity, specifically related to one's professional roles; and teaching identity, whose construction both precedes and outlasts a teacher's professional and academic training as such [5].

Teachers were students before becoming professionals, and after so many years in school they come to the profession with many pre-conceptions and ideas about what it is to educate, what it is to be a teacher, and what schools and education should look like [3]. On the other hand, educators teach in different levels, different subjects and different curricula; they may specialize in one age frame, a subject or a kind of population; they may arrive to education through a passion for teaching, the learning of an academic subject or so many other factors. In this vast scenario, how can teachers' identity be situated and defined? Is a teacher's professional identity related to education in general? Is it specific to a subject or to an age or grade level? Is it tied to a particular curriculum model? What constitutes a teacher's "sense of Self" [6]? Nóvoa [7], states that the construction of teachers' professional identity is a confrontation between "powers and counter- powers" as interpreted by the self, rooted not only in current practices, people and events, but also in elements of ontological security and safeness.

In early childhood, teaching identity is also defined in distinction from other levels of education. Furthermore, the fact that most classroom teachers are the main curriculum practitioners for the largest part of the school day brings to the fore an even stronger need for personal identification with the curriculum, stressing the intertwine between the personal and the professional in a particular way [7].

This identity is also deeply connected to the career stage the teacher is at, and it may shift and change depending on the length of the teaching experience, the school setting or the belonging to professional or pedagogical associations. If in the beginning of their teaching lives young professionals are often more concerned about "surviving" [2] through their day and school year, more seasoned teachers often turn to a new way of teaching as a means to ground, rethink or shift their professional identities. A recent study [5] suggests that although pre-service experiences are deeply influential in the definition of teachers' curriculum beliefs and philosophies, part of this influence is then weakened by the particular contexts in which teachers work at any given time in their careers.

\section{Curriculum Models}

Even though curriculum might be defined as not what is prescribed in school or theoretical documents, but instead as what in fact happens in the classroom, these "theoretical prescriptions" constitute the construct that defines a curriculum model [8]. Although historically, the first curricula (such as the ones defended by Plato or Rousseau) expressed philosophical ideas more than practical directions, by the latenineteenth century Froebel proposed specific materials and activities for his educational system, bringing the ideas of 
curriculum and curriculum model closer together.

In the rise of the twentieth century, Montessori and Steiner are examples of pedagogues who defined very specific curriculum models to be applied in the classroom, with clear directions about how to implement them. The notion of a curriculum model as an "ideal representation of the essential philosophical, administrative, and pedagogical components of a grand educational plan" [9], may manifest in different ways. These may be in the images of the role of the teacher [10], or expectations on the student's initiative and response [11], and reveal different ways of seeing each curriculum and model. One other way to categorize a pedagogical model could be, as Spodek [12] defines, according to its sources, be they the child, first, and then other elements, namely: developmental theories; learning theories; elements of assessment; and contents to be learned. Evans, on the other hand, establishes three indispensable components that, independent of its particular characteristics, define a curriculum model as such: theoretical grounds, administrative politics and contents, and methods. Assessment and evaluation might also be included in this definition [9].

\section{The curriculum models and schools studied in this research: Waldorf Pedagogy and MEM - Movimento da Escola Moderna ("New School Movement")}

\subsection{Waldorf Pedagogy and the Waldorf school in this study}

Based on the ideas of Rudolf Steiner, Waldorf Pedagogy is the curriculum model within the educational theory of Anthroposophy. The fact that this model exists as part of a broader philosophy that extends far beyond education, addressing fields as diverse as architecture and health, uniquely positions Waldorf Pedagogy amongst other curriculum models, extending its scope and grounding its theories.

The first Waldorf School came to be in 1919 in Stuttgart, Germany, located in Waldorf-Astoria's cigarette factory (hence its name). The central element that characterizes Waldorf education worldwide is, according to Sabmannshausen e Kügelgen [13], the teachers' disposition to a continuous self-education and development in their encounters with children. This element of constant self-reflexivity is crucial for every educator, and takes place both in daily practices and in local and international gatherings and professional and personal development activities.

The Waldorf school system is organized in three coordinated but distinct stages, corresponding to seven-year periods in students' lives. On the first period, 0-7 years, the school's focus is set on bodily action, in the development of the physical body; from 7-14 years stronger attention is given to the students' emotional growth; and the last period, from 14 to 21 years, is devoted to the development of thought and cognitive and intellectual abilities.

Some elements are common to all levels: throughout the school years, artistic and manual activities have a strong presence in the curriculum, as well as storytelling and physical activities. Most subjects are taught in blocks of time and content along each school year, in a dual year-long and schoolsystem-long organization that creates a rhythmic immersion in each curricular theme, and gives the schooling process its strong unity and coherence. In Waldorf Pedagogy, the teachers' role is pivotal as a curriculum leader, although the curriculum itself is defined and determined by the model's philosophy and guidelines. Waldorf teachers are expected to have a deep understanding of Anthroposophy's views on child development and of the model's methods and curriculum, structuring the days according to these two main elements. At the school, the teacher is also responsible 
for creating and maintaining an environment that is considered appropriate to the children and their development, paying careful attention to aesthetics. The education and training of Waldorf teachers is very specific to the model and takes place both in Waldorf universities and in professional seminars, conferences and meetings worldwide.

The Waldorf school studied in this research was founded in Lisbon, Portugal in the early 1980's by a group of parents. These parents, knowledgeable in Anthroposophy, specifically wanted their children to attend a Waldorf school—at the time inexistent in the surrounding areaand in this way were driven to the school by the curriculum model itself. Waldorf Pedagogy has then driven the school's existence since the very beginning, defining its core, its philosophy and its practices. All teachers in the school have Waldorf training (or are in the process of receiving it), and regularly attend international meetings and seminars within the model. Being a school small in size, there is only one preschool room, where the data for this study was collected, and one infant/ toddler room.

The teacher participating in this research has a long and strong connection to Waldorf Pedagogy, having studied it and worked within it for many years. Although her initial training was in psychology and with no relation to this kind of model, at a young age she encountered Waldorf Pedagogy and immediately felt a strong connection with it, altering the course of her studies to dedicate herself to Anthroposophy.

\subsection{MEM - Movimento da Escola Moderna (“New School Movement”) and MEM school present in this study}

MEM, Movimento da Escola Moderna, is the Portuguese interpretation of Freinet's New School ideas which were developed in France in the early- twentieth century. Although it is part of the international movement based on Freinet's pedagogical thoughts, MEM was officially founded in 1966 as a national and independent association actively dedicated to the cooperative self-education of its members, and to the dissemination of its curriculum and methods.

Throughout the years, MEM has constructed the Modelo Escola Moderna Portuguesa (Portuguese New School Model), developing Freinet's ideas and adapting them to the current Portuguese context. This development, however, is a revision more than a translation, and although maintaining the same principles and philosophy, it encompasses a theoretical shift: from Freinet's more empiricist view of learning as a trial and error process, this model evolves towards a more instructional line based on Vigotsky and Bruner, shifting the focus of education and classroom practices from expression to communication, and centering the curriculum not in the children themselves but in their social interactions in a democratic context [14].

In this model, school is seen as a democratic community, having as main goals the initiation to practices of democracy, the re-establishment of educational and social meanings and values, and the cooperative reconstruction of culture [14]. The student council is the center of the classroom life, and it decides upon daily and extraordinary matters. The school day is based on a balance of class meetings and independent and group activities, giving each child the chance to actively participate in determining his or her learning activities and in decision making concerning the classroom and the school contexts.

In the classroom, the teacher is seen as a facilitator with an active role in providing the class and each student with the environment and the materials necessary for their learning, their development and their engagement in practices of democracy. More than an instructor, the teacher is a resource, responding to the student's needs 
and ideas and accompanying them in their individual and community paths.

The teachers who work with this model receive their professional certification from the State and may be trained in any higher education institution, engaging in MEM's training (through cooperative groups, conferences, seminars and MEM programs) in addition to their initial general training and certification.

In this study, the school working with MEM was founded in the 1960s, in response to the political and ideological apprehensions of a group of parents concerned with their childrens' education during the latest period of the Portuguese authoritarian regime. Based on ideas and ideals of democracy, this school has aimed since its creation to educate citizens, teaching democratic and cooperative principles. Although being a member of Associação Movimento Escola Moderna Portuguesa is not required to work in this institution, most teachers in the school are part of this association and undergo continuous training and professional development within the model. Although not formally required, this willingness to participate in the Movement's training and activities is, as stated by the school's director, considered as an important asset in the hiring of new teachers.

The teacher participating in this study is an active member of Associação Movimento Escola Moderna Portuguesa, having a deep personal and profession connection to the model's foundations and ideas. Although her pre-service training was not based in any specific curriculum model, she recognized herself in MEM and fully embraced its ideals and methods from the early stages of her career. She extensively volunteers her time and manpower in the association's activities, seminars, and cooperative professional development groups.

\subsection{Working with no defined curriculum model: the school present in this study}

The third school in this research does not adopt a specific curriculum model. It is a school with a strong pedagogical tradition of developing a curriculum based on artistic and cultural values and activities since it was founded in the late 1960s in Lisbon. As the other two schools in this study, this school was born out of the initiative of a small group of parents who aimed to create a school that would respond to their educational ideas and concerns. Mostly about fostering self-esteem, responsibility, autonomy and success, these concerns were grounded in the belief in the importance of artistic and cultural experiences in school.

Being a small school, there is only one preschool/ kindergarten classroom (for which the teacher participating in this research is responsible), although the school also houses grades 1 to 4 in two classrooms of mixed groups. Communication is seen as a key element in the school, and students are encouraged to express themselves and their ideas in numerous venues. Many of the decisions concerning school and classroom life are made through votes and / or consensus, in community meetings attended by all children and teachers.

There is no specific training required by the school, and the candidates' personal values, teaching styles, and personalities are considered in the recruitment and hiring of new teachers. Another element taken in consideration is the candidates' school of education: since training in a specific model is not required, preference is given to schools that value a broader approach and present their students to several curriculum models.

The teacher interviewed in this research was not initially trained in any specific model, but attended a school of education that introduced her to different ways of being in the classroom. Although she was not extremely aware of the characteristics and believes of different curriculum models 
and did not specifically look to one way of teaching for herself, from the time she graduated she had clear ideas about the types of practices that she did not wish to embrace.

\section{Discussion}

Although both curriculum models studied in this research, Waldorf and MEM, have very distinctive characteristics, data suggests that they do fulfill a role that may be similar for these two teachers, that is less present in the practice and the ideas of the teacher working without a specific model.

\subsection{The need to belong}

Both teachers working within a specific curricular framework consider having a pedagogical model as essential to their teaching, as something that "expresses the vision of what it is to educate" (Waldorf Teacher), that helps the teacher to draw nearer to her ideals about education, and that prompts them to question how to act and how to be with children. More than that, a model is something to which the teacher "belongs" to in a deep way, both on a professional and personal level, and it is most meaningful when a strong personal connection exists as well. When this personal identification exists, the Waldorf teacher (WT) argues, the model is more than a mere support for action or a "walking cane" for teaching.

This idea of receiving support from a larger pedagogical framework is also shared by the teacher working without a model (NT), although with reference to a philosophy of education rather than a more formal curricular model. This teacher states that curriculum models should not be taken too strictly due to their general nature. Because these models are not designed by the teachers themselves, they will always "sound fake" (NT) if taken and applied literally.
The MEM teacher (MT) also recognizes the importance of a model, although acknowledging that if the curriculum is based in, for example, an extremist ideology, it may be "dangerous." Yet this teacher also describes believing that working without a curriculum impoverishes schools in their coherence and institutional identity and has a negative impact in classroom practices.

A strengthening of the community aspect of a school is something that may be provided by a curriculum model or a strong philosophy, and as such, the three teachers agree on the importance of belonging to a broader community of thought. A model helps teachers to feel part of a larger network of peers and, adds the Waldorf Teacher, helps in not feeling lost or alone in their practices. The NT also brings up school coherence as a crucial factor in a school's sense of community, stating how important it is for the school to have a leadership that determines the general teaching lines, establishing a school philosophy, that would for her substitute a formal pedagogical model.

\subsection{Intertwining of the personal and professional}

Being dedicated professionals, these three teachers give their schools and their classrooms much of their personal energy, time and attention. All three teachers are personally very attached to their curriculum model and / or their school and classroom, and they describe that their job is part of who they are. Furthermore, both the Waldorf teacher and the teacher working without a specific model have positions of added responsibility and leadership in their schools. The teacher working without a model is in fact not only the school director but also became its owner, having a financial interest in the school as well.

This intertwining exists because the models or philosophies these teachers chose directly relate to the ways in which they live 
their lives and the ideas that guide them. All three describe how their professional contexts give them answers to their personal quests and concerns, and how the encounter with the model, in the case of the Waldorf and MEM teachers, deeply influenced their personal selves and their lives.

The Waldorf teacher explains how not only the curriculum model but also Anthroposophy in itself has intensely shaped her life. Her encounter with the model came in a time of profound disappointment with the college experience she was having while studying psychology, and she immediately and fully embraced this new discovery. She willingly altered her professional and life path, and she joined the anthroposofical movement to study pedagogy, having also moved abroad. Within the movement, where she has been ever since, the Waldorf teacher underwent other professional trainings along with teaching, and throughout her life has been professionally exploring other educational and therapeutic practices both in and outside of school.

This strong connection to the model's ideas is shared by the MEM teacher, who stresses how her professional and personal lives are completely intertwined in every aspect. In Movimento Escola Moderna she finds a response not only to her professional needs, but also to her personal values, inquiries and quests, and she fully embraces the movement's ideas in her philosophy of life. For this teacher, belonging to MEM is like "being a militant," with the kind of deep emotional, ideological and philosophical liaison one should feel with the political party one associates oneself with. This teacher's undergrad studies in education did not reflect any particular model, and for the first couple of years of her professional life she worked in a school with no defined model or philosophy. However, when the opportunity of joining one of her close friends in the school where she teaches now came up, the MEM teacher jumped for it, recognizing herself in the institution's principles and ideas. Her involvement in MEM and her professional development and training in the model have happened continuously ever since, and she is an active member of Movimento Escola Moderna and of her school. This teacher has an even stronger bond between her personal and professional contexts, since her husband is also a teacher in the model and in the school, and events such as professional meetings at their house, evenings of lesson planning, or weekends spent in the association headquarters are part of their routines and daily lives.

This intertwining of personal and professional is, the teacher working without a model also believes, inevitable. Education in itself is such a vast field, NT states, it connects so many different aspects and values, that the professional and personal sides of a teacher's life can never be experienced fully apart. Coming from a general teaching training as well, she was more alert to what she did not want as a teacher than to what she did, and although she was not looking for any particular model or philosophy when she first starting searching the job marked for a teaching position, she knew she would need to have a personal connection to her teaching context. When she applied for her first job as a teacher - in the school where she teaches now, and which she never left - NT did so because she recognized in this institution the responses to her professional needs, along with this personal identification with the school's philosophy. This recognition and identification with the school came forth in an even stronger fashion when, a few years after NT joined the school, the director/ owner decided to retire and sell the institution. At this point NT stepped in and, with a colleague, became one of the two owners. Although this situation did not last long - her colleague and her parted ways after a couple of years - NT never left that school, establishing a new partnership with her husband, also a teacher. 
For both WT and MT, the more significant and life changing professional choices were made in direct relation to their models, choosing to move jobs, countries and positions to work within the pedagogy they believe in. both these teachers shape their personal and professional lives together, and the choice to work with the curriculum model they do is present in their personal life decisions. The teacher with no specific model, although having taught in the same school and according to the same philosophy throughout her teaching life, has nevertheless a particular stance on her circumstances: her professional "life changing" moment is not related to a model or to the school's philosophy per se, but concerns her decision to establish a business partnership to own the school, which was about to close when the previous owner retired. Although this is definitely a schoolrelated decision and was certainly influenced by her personal commitment to the school's philosophy, this teacher refers to this decision and to the changes it brought more within the management and commercial aspects of it than the curricular, pedagogical, or philosophical aspects.

\subsection{What it is to be a teacher}

In the cases of these three teachers, the model also seems to determine the way each person sees themselves as teachers and in the roles they assume in their classrooms. These three teachers see their roles as teachers in different ways, which are very coherent in the cases of the Waldorf and MEM teachers, to their models' guidelines and philosophies.

The Waldorf teacher sees herself as a motherly figure and as the guardian of the space of her classroom and her school, providing an environment that serves her children in its aesthetic, practical and spiritual aspects. She points out the importance of maintaining a loving and beautiful environment, with the right physical and spiritual nourishment, and describes how she does so by being selfreflexive about her teaching and the environment she is providing, by studying the model in-depth, and by observing her children, deciding what, according to Waldorf principles, would be the best way to provide for them. Of these three educators, the Waldorf teacher is the only one who is not certified by the Portuguese State and did not undertake any formal training outside her pedagogical, philosophical and curriculum model. Being so, her way of teaching and of understanding her role as teacher are strictly determined by the model and the training and experiences she has had within it.

On the other hand, the teacher working without a specific model had a very general training, and her views of early childhood education and of the characteristics of good teaching are quite encompassing. This teacher stresses the need to empower to each child's voice, making her students feel important and welcomed in their individuality. She sees herself as a role model for her children, and her efforts are geared towards presenting to them a good image of herself that the children can look up to. In her classroom, she follows the children's interests and ideas and makes sure every child has a chance to be heard and to let her or his ideas be known. The aesthetic aspect of the classroom is not as crucial for her as the flexibility of the space and that it corresponds to children's needs and interests at any given moment, and this teacher uses what materials she has at hand to decorate and make use of the space.

Children's voices are also crucial for the MEM teacher. Not only are they important, but they guide the classroom activities and the curriculum, and it is this teacher's assumed role to serve and assist her students in their problem-solving, decision making, and learning processes. The MEM teacher refers to herself as a "secretary" to the children, in the sense that she helps them in writing and organizing their ideas and communications, all under the assumption 
that such encourages the practices of democracy. Her classroom is a mirror to whatever is going on at any given moment, and documentation of individual and group projects and investigations are an important element of such a classroom.

All three teachers see their role as mainly educational (as opposed to only providing child care) and, although the specifics of what they consider import vary, each are very aware of the importance of their role and of the way they may influence their students in their current and future growth and development at all levels. They all see their classrooms as their prime space, and recognize the way they organize and in some cases decorate it as an important aspect of their teaching.

\section{Conclusions}

The personal connection to their schools' curricular model or philosophy is crucial for these three educators, both personally and professionally. This relationship, however, manifests uniquely for each teacher, in a different type of dynamic of what Dubar refers to as different transactions between the biographical and the relational aspects in the teachers [15]. If for the Waldorf and MEM teachers the model is more of a lifestyle than merely a teaching tool, the teacher without a model has a more instrumental relationship with her school's philosophy which, although it does indeed match the teacher's personal values, is more valuable to her as a professional endeavor.

The Waldorf and MEM teachers, however, also mention a more practical dimension of their models with explicit consequences for their teaching. This happens mostly by their stressing of specific aspects that are addressed by their curricula and that help them in a two-fold way: personally, by helping them to "be better people" (MT), working towards an ideal in which they believe; and in their daily work, grounding their teaching and "forcing them" by the virtue of the curriculum's specific characteristics to practice the values and ideals they embrace as teachers.

This theoretical questioning instigated by the model brings with it a deep reflection about teaching and education, which was seen as more grounded in the two educators working within specific curriculum models. Although all three teachers believe the aims and strategies of their teaching practices to be the most adequate ones that more closely relate to what they believe the aims of early childhood education should be, they differ in exactly how. Both MEM and Waldorf teachers define their positions grounded not only in their practices but also in what stands behind them, allowing them a depth of questioning and self-reflexivity that comes through in well-rounded and articulated discourses about their beliefs and practices; the teacher working without a model, on the other hand, sets her reflections mostly in practical aspects of teaching, lacking more anchored views of the context she chooses for her educational values and strategies.

In the cases of these educators, the framing of practices in a model was important in helping to determine the way they reflect about their practices and their ideals. The two educators working within formal curriculum models, defined by Silva [16] as being less dependent in the reference to concrete situations and more open to conceptual structures and deeper intellectual questioning, showed a more grounded reflection about their educational goals and aims. The other educator may be said to work with what Silva defines as a "real curriculum model" [16], as the contextual setting for a specific practice, situation or process that distinguishes itself from a formal model mostly by the different levels of abstraction they present.

For these three educators, the professional-peer work is also deeply connected to the model or school philosophy within which they teach. The NT sees as her peers other early childhood teachers in general, and builds her identity 
by opposition to lower-school teachers. Being the only early childhood teacher in her school, she looks for her peers in other contexts, namely in the college seminar she attends. The MT talks about herself both as an early childhood teacher and as a MEM teacher. Although other early childhood teachers both within and outside of her school are seen as peers, other MEM teachers are regarded in the same way independent of the level they teach. In her MEM cooperative work groups, teachers of all grade levels team up in task-related or interest groups. The WT, on the other hand clearly identifies herself as a Waldorf practitioner, extending the scope of her identity even beyond education, reaching into the therapeutic and psychological fields. She does not recognize her peers in other Portuguese educators (neither in Waldorf nor in other schools), but rather finds them in the international anthroposofical movement, with which she clearly identifies.

As a conclusion, we might say that each of these educators builds her professional identity in a distinct way, although the presence of a model is crucial in both the WT and MT cases. For the NT, the core of her identity lies within early childhood teaching; for the WT it lies within the model, as she defines herself as a Waldorf professional more than as a teacher of a specific age group; and for the MT, she sees herself as deeply committed to both the pedagogical model and early childhood education in general, finding her peers and defining herself in both realities.

In this sense, to the question of what indeed shapes these early childhood educators' professional identities, one might answer that this construction is built in the interaction of the reflections and questionings from the teachers about themselves and their practices, the relationships they establish with the professional communities they belong to, and the educational practices such relationships and affiliations bring forth.

\section{References}

[1] Bodgan, R. Biklen, S., Investigação Qualitativa em Educação: uma introdução à teoria e aos métodos. Porto Editora, Porto, 1994.

[2] J. Oliveira-Formosinho, "O desenvolvimento profissional de educadores de infância principiantes. Relato de uma investigação", Infância e Educação: Investigação e Práticas (Revista do GEDEI), 2, Minho, GEDEI, pp. 109-124, 2000.

[3] Cabral, M., Dos Modelos Pedagógicos à Construção da Identidade: Estudo de Três Educadoras, Tese de Mestrado, Faculdade de Psicologia e Ciências da Educação da Universidade de Lisboa, Lisboa, 2006.

[4] A. Lopes, "Profissão e profissionalidade docente: o caso do $1^{\circ}$ CEB”, A Educação entre o local e o global na viragem do milénio, Faro, SPCE, 2001, pp 71-78.

[5] A. Lopes, and R. Tormenta, "Pre-service teacher training, primary teachers' identities and school work", Literacy Information and Computer Education Journal, 1(1), 2010, pp. 83-92.

[6] S. Hall, "The question of cultural identity", Hall, S., Held, D., MaGrew, T. (eds) Modernity and its Futures, Polity, Cambridge, 1993.

[7] Nóvoa, A., Histoire \& Comparaison (Essais sur l’Éducation) Educa, Lisboa, 1998.

[8] M. I. L. Silva, "Para nos começarmos a entender", Revista $n^{\circ} 12$ da APEI, APEI, Lisboa, 1989, pp 5-7.

[9] Evans, E. D., "Curriculum Models and Early Childhood Education”, Spodek, B. Handbook of Research in Early Childhood Education. The Free Press, New York, 1982, p. 107.

[10] T. Vasconcelos, "Imaginar o currículo", Revista da APEI n¹3, APEI, Lisboa, 1990, pp 18-20.

[11] D. Weikart J., Stanley (Ed.) Preschool Programs for the Disadvantaged, The John Hopkins University Press, London, 1972, pp.22-66.

[12] T. Vasconcelos, "Quais são as origens do currículo na educação pré-escolar?” Cadernos da APEI n²8, APEI, Lisboa, 1993, pp 8-14.

[13] Sabmannshausen, W. and Kügelgen, H., en torno al Jardín de Infancia Waldorf, Cuadernos Pau de Damasc, Barcelona, 2002.

[14] S. Niza, "O Modelo Curricular de Educação PréEscolar da Escola Moderna Portuguesa”, Oliveira Formosinho, J. (org.) Modelos curriculares para a Educação de Infância, Porto Editora, Porto, 1996.

[15] DUBAR, C., A Socialização. Construção das Identidades Sociais e Profissionais, Porto Editora, Porto, 1997 
Literacy Information and Computer Education Journal (LICEJ), Volume 3, Issue 2, June 2012

[16] SILVA, M. I. L., Práticas Educativas e Construção de Saberes: Metodologias de Investigação-Acção, Instituto de Inovação Educacional , Lisboa, 1996. 